\title{
Cardiovascular Disease Risk Factors and Knowledge Level in Nursing
}

\section{Students}

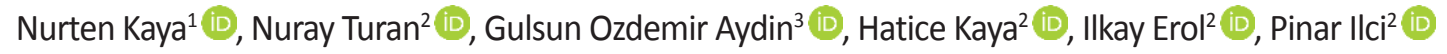 \\ ${ }^{1}$ Istanbul University-Cerrahpasa, Health Sciences Faculty, Istanbul, Turkey \\ ${ }^{2}$ Istanbul University-Cerrahpasa, Florence Nightingale Faculty of Nursing, Istanbul, Turkey \\ ${ }^{3}$ Tekirdag Namik Kemal University, Health High School, Nursing Department, Tekirdag, Turkey \\ Correspondence Author: Gulsun Ozdemir Aydin \\ E-mail: gulsunozdemir@nku.edu.tr, gulsunhemsire@gmail.com \\ Received: 05.07.2017 Accepted: 03.04.2018
}

\begin{abstract}
Objective: In recent years, cardiovascular disease (CVD) and CVD-related deaths have been increasing in the young population in Turkey. Nursing students should be informed about CVD and should reduce their own risk of this disease. This study was conducted to determine the impact of the knowledge of CVD risk factors among nursing students on the results of risk assessments.

Methods: The population of study, which had a cross-sectional design, was composed of 587 students in nursing school at one university. The sample comprised 351 students who volunteered to take part in this study. The data were collected using the Cardiovascular Disease Risk Factors Knowledge Level (CARRF-KL) Scale, The Students' CVD Risk Factors Information Form, a physician scale, a tape measure, a digital blood pressure monitor, a glucometer and cholesterol and triglyceride measuring devices.

Results: The majority of the students (77.2\%) were female, and the mean age was 20.77 years. The CARRF-KL Scale scores of the participants were low. In a significant majority of the sample, the anthropometric measurement results, blood pressure, respiration rate, pulse rate, blood glucose level, cholesterol level, and triglyceride level were within normal limits. As the knowledge level of CVD risk factors increased among the students, the blood glucose and cholesterol levels decreased.

Conclusion: Although they were in the minority, some of the nursing students in the sample had an increased risk of CVD. Health screening programs should be performed more often at institutions that educate health professionals. Strategies for reducing the CVD risk in the risk students should be conducted, and these students should be monitored closely.
\end{abstract}

Keywords: Assessment, cardiovascular disease, knowledge level, nursing students, risk factors

\section{INTRODUCTION}

Cardiovascular disease (CVD) is a major cause of mortality and morbidity especially in low to middle income countries. Eighty percent of CVD-related deaths occur in developing countries. The main risk factors for CVD are age, smoking, diabetes, hypertension, high levels of low-density lipoproteins (LDLs), high levels of triglycerides and homocysteine, low levels of high-density lipoproteins (HDLs) and obesity (1-4). Social behavioral models suggest that knowing the negative consequences of individual's behavior on his/her health is the basic factor in behavioral change. Since insufficient knowledge would cause insufficient motivation in lifestyle and behavioral changes, CVD prevention activities focus on community-based education programs (1).

Today, nearly half of the young population is at risk for CVD in the world (5). One of the goals of health for 21st century of the World Health Organization's (WHO's) European Region is "to provide young people with a healthier life and the ability to better fulfil their roles in the society in a healthy way by the year 2020". While this goal indicates the importance and necessity of health services that protect and improve young people's health, it requires early diagnosis, appropriate care, treatment and regular screening for CVD and other diseases associated with CVD-related deaths (6). The main purpose of CVD risk screenings is to detect the early signs of the disease and to decrease mortality and morbidity by identifying the CVD risk factors in healthy individuals (7).

Even though Turkey has a young population compared to other European countries, the CVD morbidity rate is higher $(8,9)$. Recently, the prevalence of several CVD risk factors has increased among subsets of young adults. Factors known to increase the risk of CVD include age, obesity, central distribution of body fat, smoking, physical inactivity, hypertension, dyslipidemias and abnormalities in blood clotting for young people. Several screening studies on the prevalence of obesity in Turkey have shown that it is a major health problem, with increasing prevalence in younger age groups $(10,11)$. While physical activity decreased (male: $2.3 \%$, female: $6.3 \%$ ) each year since 1990 , hypertension incidence increased by 21.3\% between 2003 to 2007 (12). Considering their ages, university students were expected to be at risk for $C V D$, and a screening program was designed. The effective risk management of CVD requires multidisciplinary cooperation in prevention and treatment as well as greater university student, his/her family, and community involvement and a skilled, proactive, and diverse workforce (9). 
CVD risk screening in nursing students is also important for several reasons: (1) the incidence rate of CVD in young people has increased, and nursing students are in this age group; (2) this group of university students is studying a health-related field, and they should be role models of health-related behaviours for other university students and the society in general; and (3) after graduation, these students will be responsible for the care and treatment of healthy and sick individuals in the community, and therefore, they themselves should be healthy; the first step toward developing positive health-related behaviours in individuals is to diagnose their current health risks (13).

Additionally, it is important that nursing students are informed about CVD so that they can protect themselves against this disease, have regular screenings and receive the necessary care and treatment if diagnosed with CVD. This knowledge and experience will allow nursing students to actively provide care and consulting services in health care after their graduation. Furthermore, students' knowledge level are very important for designing educational programs that provide information on CVD risk factors, thus determining the effectiveness of these programs and monitoring the CVD risk factors of participants $(5,14)$. Despite the need for nurses to provide education to help reduce CVD-related morbidity and mortality in Turkey, no studies have been published of nursing students' knowledge and personal health behaviors related to CVD and related risk factors. In addition, it is important to determine the knowledge level of CVD risk factors and the ability of these students to obtain and evaluate their risk assessment results.

\section{Objectives ;}

This cross-sectional study was conducted to determine the knowledge of CVD risk factors/ and relationship students' have risk factors among nursing students. The research questions were as follows:

1. What are the knowledge levels of CVD risk factors and the risk assessment data of the students?

2. Does the level of knowledge regarding these risks affect the risk assessment data?

\section{METHODS}

\subsection{Participants and setting}

The study population comprised 587 nursing school students from one university during the 2010-2011 academic year and the sample comprised 351 students $(59.8 \%$ of the study population) who volunteered to participate in this study. According to population and sample number, the results of present study reflected a 3.32 error rate and 0.95 confidence interval.

\subsection{Instruments}

Data were gathered using The Cardiovascular Disease Risk Factors Knowledge Level (CARRF-KL) scale and a risk assessment questionnaire.

Cardiovascular Disease Risk Factors Knowledge Level (CARRF-KL) Scale: This scale was prepared by Arikan et al (1), validity and reliability study was performed and the Cronbach's alpha coefficient was 0.85 . The Cronbach's alpha coefficient from the data obtained in this study was 0.68 . This result indicates a good reliability of the data. Of the 28 items in the CARFF-KL scale, the first four pertain to CVD characteristics, the next 15 pertain to risk factors and the last nine assess the effects of changes in risk behaviours. In this study, the items were presented in the form of a sentence that was either correct or incorrect, and the participants were asked to answer "Yes", "No" or "Do Not Know". Scoring was performed such that one point was given for each "correct answer", and zero points were given for each "Do Not Know" or "wrong answer". Six items in the scale (items 11, 12, 16, 17,24 and 26) were coded inversely. The minimum score that could be obtained was zero, whereas the maximum score was 28. A higher score indicated a higher knowledge level (1).

The Students' CVD Risk Factors Information Form: This questionnaire was developed from the literature (5,15-19) by prior researchers, and it was used to record age, gender, class, using smoke and alchol, the height, weight, waist and hip circumferences, arterial blood pressure, pulse rate and respiration rate as well as blood glucose, cholesterol and triglyceride values.

\subsection{Equipment and Calculations}

Physician scale: This scale provides measurements based on gender. It measures height and weight, and it displays BMI value on a digital screen. Weights between 0 and 200 $\mathrm{kg}$ and heights between 90 and $200 \mathrm{~cm}$ can be determined accurately with a sensitivity of $\pm 50 \mathrm{~g}$ and $\pm 1 \mathrm{~mm}$, respectively. The BMI of each student was recorded and classified using the scheme depicted in Table $1(15,16)$.

Table 1. BMI* Score Assessment Table

\begin{tabular}{|l|l|l|}
\hline & Males & Females \\
\hline Underweight & $<20$ & $<19$ \\
\hline Ideal Weight & $20-25$ & $19-24$ \\
\hline Overweight & $26-30$ & $25-30$ \\
\hline Obese & $>30$ & $>30$ \\
\hline
\end{tabular}

*Body Mass Index

Tape measure: A tape measure was used to measure the waist and hip circumferences. The purpose of the Waist-To-Hip Ratio Test was to assess the waist-to-hip circumference ratio associated with coronary heart disease risk. In the test, the waist and hip circumferences were measured, and the waist circumference value was divided by the hip circumference value. Table 2 shows the acceptable and unacceptable 
waist-to-hip circumference ratio ranges (16) and the waistto-hip ratio classification scheme used in this study.

Table 2. Waist/Hip Circumference Ratio Classification

\begin{tabular}{|l|c|c|c|c|}
\hline \multirow{2}{*}{} & \multicolumn{2}{|c|}{ Acceptable } & \multicolumn{2}{c|}{ Unacceptable } \\
\cline { 2 - 5 } & Perfect & Good & Mediocre & High \\
\hline Male & $<0.85$ & $0.85-0.90$ & $0.90-0.95$ & $>0.95$ \\
\hline Female & $<0.75$ & $0.75-0.80$ & $0.80-0.85$ & $>0.85$ \\
\hline
\end{tabular}

Digital arterial blood pressure measurement device: An upper arm digital blood pressure device was used to measure blood pressure accurately and comfortably. For an accurate measurement, the cuff that best fit the upper arm was selected (small/medium cuff $=23-33 \mathrm{~cm}$ arm circumference, large/extra-large cuff $=33-43 \quad \mathrm{~cm}$ arm circumference). Measurements were taken in accordance with the standard procedures for measuring blood pressure. The measurement results were displayed on the screen as systolic and diastolic pressures in " $\mathrm{mmHg}$ " units. The pulse rate was also displayed on the screen of the device. Students' arterial blood pressure data were recorded as systolic and diastolic pressures, and values higher than 130 and $80 \mathrm{mmHg}$ for systolic and diastolic arterial blood pressures, respectively, were considered high $(15,17,19)$.

Glucometer: The glucometer used in this study measured the blood glucose level in blood taken from the fingertip. If the blood glucose level result was lower than $20 \mathrm{mg} / \mathrm{dL}$ or higher than $500 \mathrm{mg} / \mathrm{dL}$, then "LOW" or "HIGH", respectively, appeared on the screen of the device. In this study, no low or high values were detected. Blood glucose levels were measured regardless of whether the students had eaten; however, depending on the time at which the students had eaten their last meal, their blood glucose level results were evaluated with respect to their fasting and postprandial durations. The students who had fasted for too long ( 12 hours or more) had their blood glucose measurements repeated postprandially. In classifying the blood glucose level values, $140 \mathrm{mg} / \mathrm{dL}$ was accepted as the upper limit $(15,18)$, and the evaluation of the data was performed accordingly.

Cholesterol and triglyceride measurement device: Using device-specific cholesterol and triglyceride strips, the total cholesterol and triglyceride levels were measured in the capillary blood. This device performed the measurement using reflectance photometry. The measurement ranges of the device for cholesterol and triglycerides were 150-300 $\mathrm{mg} / \mathrm{dL}$ and $70-600 \mathrm{mg} / \mathrm{dL}$, respectively. When a value lower than the detection range of the device was detected, "LOW" appeared on the screen, and when a value higher than the range was detected, "HIGH" appeared. No high cholesterol or triglyceride values were found in the study. However, cholesterol values less than $150 \mathrm{mg} / \mathrm{dL}$, which were labelled as "LOW", were recorded as $149 \mathrm{mg} / \mathrm{dL}$ in the database to perform calculations. Similarly, low triglyceride values were recorded in the database as $69 \mathrm{mg} / \mathrm{dL}$. The duration of measurement was 180 seconds for cholesterol and between 45 and 174 seconds for triglycerides. The cholesterol values were classified as less than $200 \mathrm{mg} / \mathrm{dL}$, between 200 and $239 \mathrm{mg} / \mathrm{dL}$ and greater than $240 \mathrm{mg} / \mathrm{dL}$ (20). The triglyceride values were classified as less than $200 \mathrm{mg} / \mathrm{dL}$, between 200 and $400 \mathrm{mg} / \mathrm{dL}$ and greater than $400 \mathrm{mg} / \mathrm{dL}(18,19)$.

\subsection{Data collection}

The each student who agreed to participate in the study was taken into a room that was specifically allocated and designed for this study. First, the CARRF-KL scale was administered, and the students were asked to complete this form. Next, the height, weight, arterial blood pressure, pulse rate and respiration rate and blood glucose, cholesterol and triglyceride values were measured and recorded in the specified sections on the forms.

\subsection{Ethical aspects of the study}

The investigation was conducted in accordance with the principles outlined in the Declaration of Helsinki. Furthermore, the Istanbul University Cerrahpasa Faculty of Medicine Clinical Research Ethics Committee determined that the study was ethically compliant. An application was submitted to the director of the school where the data were collected with information on the purpose and content of the study, and written informed consent was obtained. The students that comprised the study sample were informed of the purpose of the study, its benefits and their roles in the study. Participants were informed of the voluntary nature of their participation in the study, and written and verbal consents were obtained. Before data collection began, the students were informed that they could decline to participate in the study at any stage.

\subsection{Statistical analysis}

The data obtained from the questionnaires were recorded in a database that was created and analysed using Statistical Package for the Social Sciences for Windows (SPSS 17.0). In the data analysis, ordinal variables were evaluated as arithmetic means with standard deviations (SDs) and minimum and maximum values, while nominal variables were evaluated as frequencies and percentages. The Spearman's rho correlation technique, Mann-Whitney $U$ test and Kruskal-Wallis test were used to determine the relationships between ordinal variables, the difference between the means of two groups and the difference between the means of more than two groups, respectively.

\section{RESULTS}

In this section, the CARRF-KL scale scores, arterial blood pressure, blood glucose values, cholesterol values, triglyceride values, BMIs, and waist-to-hip ratios are outlined under two subheadings according to the questions addressed in the study. 
The students' knowledge level of CVD risk factors, risk assessment data

It was determined that $77.2 \%$ of the students were women and $57.8 \%$ were between the ages of 20 and 22 years old. Also the mean age of the students was $20.77 \pm 1.98$ years.

The students' mean CARRF-KL scale score was 9.44 \pm 3.23 , and the knowledge level was low.

When the risk assessment data of the male students were analysed, $71.3 \%$ of the males were at an ideal weight according to $\mathrm{BMI}, 52.5 \%$ had a perfect waist-to-hip ratio, and $83.8 \%$ had an acceptable waist-to-hip ratio, thereby posing no CVD risk. For the male students, the mean BMI was 23.62 \pm 3.16 , the mean waist-to-hip ratio was $0.84 \pm 0.55$ (Table 3 ).

Table 3. The Distribution of the CARRF-KL Scores of the Students According to the CVD Risk Factors Data $(N=351)$

\begin{tabular}{|c|c|c|}
\hline \multirow{2}{*}{ Risk Assessment Data } & \multirow{2}{*}{ n (\%) } & CARRF-KL ${ }^{\S}$ \\
\hline & & Mean \pm SD \\
\hline \multicolumn{3}{|l|}{ Body Mass Index (Male) } \\
\hline \multirow{4}{*}{$\begin{array}{l}\text { Underweight }(<20) \\
\text { Ideal weight }(20-25) \\
\text { Overweight }(26-30) \\
\text { Obese }(>30)\end{array}$} & \multirow{4}{*}{$\begin{array}{c}8(10.0) \\
57(71.3) \\
13(16.3) \\
2(2.5)\end{array}$} & $8.38 \pm 1.92$ \\
\hline & & $9.86 \pm 4.32$ \\
\hline & & $\begin{array}{l}9.62 \pm 4.37 \\
9.00 \pm 4.24\end{array}$ \\
\hline & & $x^{2}=0.65^{*} p=0.89$ \\
\hline $\begin{array}{l}\text { Body Mass Index (Male) } \\
\text { (Mean } \pm S D) \text { (Min.-Max.) }\end{array}$ & $\begin{array}{c}23.62 \pm 3.16 \\
(16-39)\end{array}$ & $r=-0.12 * * p=0.30$ \\
\hline \multicolumn{3}{|l|}{ Body Mass Index (Female) } \\
\hline \multirow{4}{*}{$\begin{array}{l}\text { Underweight }(<19) \\
\text { Ideal weight }(19-24) \\
\text { Overweight }(25-30) \\
\text { Obese }(>30)\end{array}$} & \multirow{4}{*}{$\begin{array}{c}34(12.5) \\
177(65.3) \\
54(19.9) \\
6(2.2)\end{array}$} & $9.88 \pm 3.25$ \\
\hline & & $9.28 \pm 2.90$ \\
\hline & & $\begin{array}{l}9.59 \pm 2.84 \\
7.67 \pm 1.63\end{array}$ \\
\hline & & $x^{2}=3.17 * p=0.37$ \\
\hline $\begin{array}{l}\text { Body Mass Index (Female) } \\
\text { (Mean } \pm S D \text { ) (Min.-Max.) }\end{array}$ & $\begin{array}{c}22.55 \pm 3.25 \\
(16-34)\end{array}$ & $r=-0.02 * * p=0.75$ \\
\hline \multicolumn{3}{|l|}{ Waist-to-hip ratio (Male) } \\
\hline \multirow{4}{*}{$\begin{array}{l}\text { Perfect }(<0.85) \\
\text { Good }(0.85-0.90) \\
\text { Mediocre }(0.90-0.95) \\
\text { High }(>0.95)\end{array}$} & \multirow{4}{*}{$\begin{array}{c}42(52.5) \\
25(31.3) \\
12(15.0) \\
1(1.3)\end{array}$} & $9.67 \pm 4.35$ \\
\hline & & $9.56 \pm 4.22$ \\
\hline & & $10.08 \pm 3.23$ \\
\hline & & $x^{2}=2.88 * p=0.41$ \\
\hline \multicolumn{3}{|c|}{ Waist-to-hip ratio according to acceptability level (Male) } \\
\hline \multirow{3}{*}{$\begin{array}{l}\text { Acceptable } \\
\text { Unacceptable }\end{array}$} & \multirow{3}{*}{$\begin{array}{l}67(83.8) \\
13(16.3)\end{array}$} & $9.63 \pm 4.27$ \\
\hline & & $9.77 \pm 3.30$ \\
\hline & & $Z=-0.57 * * * p=0.57$ \\
\hline $\begin{array}{l}\text { Waist-to-hip ratio (Male) } \\
\text { (Mean } \pm S D \text { ) (Min.-Max.) }\end{array}$ & $\begin{array}{c}0.84 \pm 0.55 \\
(0.71-1)\end{array}$ & $r=-0.003 * * p=0.98$ \\
\hline \multicolumn{3}{|l|}{ Waist-to-hip ratio (Female) } \\
\hline \multirow{5}{*}{$\begin{array}{l}\text { Perfect }(<0.75) \\
\text { Good }(0.75-0.80) \\
\text { Mediocre }(0.80-0.85) \\
\text { High }(>0.85)\end{array}$} & \multirow{5}{*}{$\begin{array}{l}92(33.9) \\
82(30.3) \\
57(21.0) \\
40(14.8)\end{array}$} & $8.99 \pm 2.66$ \\
\hline & & $9.37 \pm 2.83$ \\
\hline & & $9.74 \pm 3.21$ \\
\hline & & $9.80 \pm 3.21$ \\
\hline & & $x^{2}=2.17 * p=0.54$ \\
\hline \multicolumn{3}{|c|}{ Waist-to-hip ratio according to acceptability level (Female) } \\
\hline \multirow{3}{*}{$\begin{array}{l}\text { Acceptable } \\
\text { Unacceptable }\end{array}$} & \multirow{3}{*}{$\begin{array}{c}174(64.2) \\
97(35.8)\end{array}$} & $9.17 \pm 2.74$ \\
\hline & & $9.76 \pm 3.19$ \\
\hline & & $\mathrm{Z}=-1.22^{* * *} p=0.22$ \\
\hline
\end{tabular}

\begin{tabular}{|c|c|c|}
\hline $\begin{array}{l}\text { Waist-to-hip ratio (Female) } \\
\text { (Mean } \pm S D) \text { (Min.-Max.) }\end{array}$ & $\begin{array}{c}0.78 \pm 0.16 \\
(0.63-0.96)\end{array}$ & $r=0.08 * * p=0.19$ \\
\hline \multicolumn{3}{|l|}{ Arterial blood pressure (systolic) } \\
\hline \multirow{2}{*}{$\begin{array}{l}130 \mathrm{mmHg} \text { and } \uparrow \\
130 \mathrm{mmHg} \downarrow\end{array}$} & \multirow{2}{*}{$\begin{array}{c}36(10.3) \\
315(89.7)\end{array}$} & $\begin{array}{c}10.44 \pm 4.83 \\
9.33+2.98\end{array}$ \\
\hline & & $Z=-0.74 * * * p=0.46$ \\
\hline $\begin{array}{l}\text { Arterial blood pressure (systolic) } \\
\text { (Mean } \pm \text { SD) (Min.-Max.) }\end{array}$ & $\begin{array}{c}107.66 \pm 15.41 \\
(66-173) \\
\end{array}$ & $r=0.04 * * p=0.94$ \\
\hline \multicolumn{3}{|l|}{ Arterial blood pressure (diastolic) } \\
\hline \multirow{2}{*}{$\begin{array}{l}80 \mathrm{mmHg} \text { and } \uparrow \\
80 \mathrm{mmHg} \downarrow\end{array}$} & \multirow{2}{*}{$\begin{array}{l}81(23.1) \\
270(76.9)\end{array}$} & $\begin{array}{l}9.49 \pm 3.28 \\
9.43 \pm 3.22 \\
\end{array}$ \\
\hline & & $Z=-0.24^{* * *} p=0.81$ \\
\hline $\begin{array}{l}\text { Arterial blood pressure } \\
\text { (diastolic) (Mean } \pm S D \text { ) (Min.- } \\
\text { Max.) }\end{array}$ & $\begin{array}{c}70.09 \pm 13.42 \\
(42-105)\end{array}$ & $r=-0.02 * * p=0.65$ \\
\hline \multicolumn{3}{|l|}{ Pulse } \\
\hline $\begin{array}{l}\text { Pulse (Mean } \pm \text { SD) } \\
\text { (Min.-Max.) }\end{array}$ & $\begin{array}{c}84.18 \pm 13.06 \\
(51-150)\end{array}$ & $r=0.02 * * p=0.71$ \\
\hline \multicolumn{3}{|l|}{ Respiration } \\
\hline $\begin{array}{l}\text { Respiration(Mean } \pm \text { SD) } \\
\text { (Min.-Max.) }\end{array}$ & $\begin{array}{c}20.03 \pm 2.08 \\
(14-26) \\
\end{array}$ & $r=0.006 * * p=0.90$ \\
\hline \multicolumn{3}{|l|}{ Blood glucose } \\
\hline \multirow{2}{*}{$\begin{array}{l}140 \mathrm{mg} / \mathrm{dL} \text { and } \uparrow \\
140 \mathrm{mg} / \mathrm{dL} \downarrow\end{array}$} & \multirow{2}{*}{$\begin{array}{c}16(4.6) \\
335(95.4)\end{array}$} & $\begin{array}{l}9.00 \pm 3.12 \\
9.46 \pm 3.23 \\
\end{array}$ \\
\hline & & $\mathrm{Z}=-0.84^{* * *} \mathrm{p}=0.40$ \\
\hline $\begin{array}{l}\text { Blood glucose (Mean } \pm \text { SD) } \\
\text { (Min.-Max.) }\end{array}$ & $\begin{array}{c}100.72 \pm 19.87 \\
(38-166)\end{array}$ & $r=-0.118 * * p=0.027$ \\
\hline \multicolumn{3}{|l|}{ Cholesterol level } \\
\hline \multirow{2}{*}{$\begin{array}{l}200 \mathrm{mg} / \mathrm{dL} \text { and } \uparrow \\
200 \mathrm{mg} / \mathrm{dL} \downarrow\end{array}$} & \multirow[t]{2}{*}{$\begin{array}{c}4(1.1) \\
347(98.9)\end{array}$} & $\begin{array}{l}8.75 \pm 2.99 \\
9.45 \pm 3.23\end{array}$ \\
\hline & & $Z=-0.51 * p=0.61$ \\
\hline $\begin{array}{l}\text { Cholesterol level (Mean } \pm \text { SD) } \\
\text { (Min.-Max.) }\end{array}$ & $\begin{array}{c}152.28 \pm 9.57 \\
(149-221)\end{array}$ & $r=-0.142 * * p=0.008$ \\
\hline \multicolumn{3}{|l|}{ Triglyceride } \\
\hline \multirow[t]{2}{*}{$\begin{array}{l}400 \mathrm{mg} / \mathrm{dL} \text { and } \uparrow \\
200-400 \mathrm{mg} / \mathrm{dL} \\
200 \mathrm{mg} / \mathrm{dL} \text { and } \downarrow\end{array}$} & \multirow[t]{2}{*}{$\begin{array}{c}1(0.3) \\
11(3.1) \\
339(96.6)\end{array}$} & $\begin{array}{l}6.00 \pm 0.00 \\
9.36 \pm 4.43 \\
9.45 \pm 3.19\end{array}$ \\
\hline & & $x^{2}=2.63 * p=0.27$ \\
\hline $\begin{array}{l}\text { Triglyceride (Mean } \pm S D \text { ) } \\
\text { (Min.-Max.) }\end{array}$ & $\begin{array}{c}82.75 \pm 46.90 \\
(69-458)\end{array}$ & $r=-0.06 * * p=0.23$ \\
\hline
\end{tabular}

$\S$ CARRF-KL scale score was 9.44 $\pm 3.23,{ }^{*}$ Kruskal-Wallis, ${ }^{* *}$ Spearman's rho correlation, *** Mann-Whitney

When the risk assessment data of the female students were analysed, $65.3 \%$ were at an ideal weight according to $\mathrm{BMI}, 33.9 \%$ had a perfect waist-to-hip ratio, $64.2 \%$ had an acceptable waist-to-hip ratio, thereby posing no CVD risk. For the female students, the mean BMI was $22.55 \pm 3.25$, the mean waist-to-hip ratio was $0.78 \pm 0.16$ (Table 3 ).

When the other risk assessment data were analysed, 89.7\% of students had a systolic arterial blood pressure less than $130 \mathrm{mmHg}$; 76.9\% had a diastolic arterial blood pressure less than $80 \mathrm{mmHg}$; $95.4 \%$ had a blood glucose level less than $140 \mathrm{mg} / \mathrm{dL} ; 98.9 \%$ had a cholesterol level less than $200 \mathrm{mg} /$ $\mathrm{dL}$; and $96.6 \%$ had a triglyceride level less than $200 \mathrm{mg} / \mathrm{dL}$. The mean systolic arterial blood pressure was $107.66 \pm 15.41$ $\mathrm{mmHg}$; the mean diastolic arterial blood pressure was 70.09 $\pm 13.42 \mathrm{mmHg}$; the mean pulse rate was $84.18 \pm 13.06$ beats/ 
min; the mean respiration rate was $20.03 \pm 2.08$, breaths/min; the mean blood glucose level was $100.72 \pm 19.87 \mathrm{mg} / \mathrm{dL}$; the mean cholesterol level was $152.28 \pm 9.57, \mathrm{mg} / \mathrm{dL}$ and the mean triglyceride level was $82.75 \pm 46.90 \mathrm{mg} / \mathrm{dL}$ (Table 3).

\section{The effects of the students' knowledge of CVD risk factors on} the risk assessment data

The CARRF-KL scale scores were not significantly associated with BMI, waist-to-hip ratio, arterial blood pressure, pulse rate, respiration rate, triglyceride values, or the separately classified blood glucose and cholesterol values ( $p>0.05$ ). However, a statistically significant inverse relationship was found between CARRF-KL scale scores and the blood glucose and cholesterol values $(p<0.05)$, such that an increase in the knowledge of CVD risk factors was associated with a decrease in blood glucose and cholesterol values (Table 3).

\section{DISCUSSION}

In recent years, CVD-related mortality has decreased due to efforts focused on health promotion, disease prevention and treatment development. However, CVD is still among the leading causes of death worldwide in both men and women. After CVD occurs, it follows a chronic course, and the associated care and treatments affect the patient and the patient's family biologically, psychologically, socially, culturally and economically. Therefore, as with any other chronic disease, it is important to emphasise the importance of protective health services for CVD and the control of CVDrelated risk factors (21-23). In addition, it is important to consider the knowledge of CVD risk factors and to evaluate the risk assessment results of nursing students who will take an active role in preventive health services after their schooling is complete. In addition, despite widespread community screening for CVD risk factors, no studies have focused on the CVD risk factors in individuals who receive medical training and work in health services. Therefore, this study provides important information to the field.

In this study, the student's knowledge level of CVD risk factors was low. According to the data from the WHO, CVD was the fifth leading causes of death and disabilities in 1990 and is predicted to be the leading cause of death in 2020 . The number of deaths is expected to rise to 25 million from 14 million (23). Therefore, society's awareness of CVD risk factors must increase. However, only health professionals can provide accurate, appropriate and comprehensive knowledge to the public $(1,21)$. The low knowledge level of CVD risk factors among nursing students can be explained by their insufficient awareness of CVD. These findings suggest that nursing students may not be learning material from the courses covering CVD and may not be able to integrate the desired behaviour changes taught by these courses into their daily lives. Regardless of its cause, this finding indicates a problem that should be addressed and solved.

Because the reference ranges differ by gender, the BMI, and waist-to-hip ratio variables were analysed by gender. In terms of CVD, being male is an unchangeable risk factor. The prevalence of CVD among men is $4 \%$, while it is 3.8\% among women in Turkey (15). Women of reproductive age have 2.54.5 times less CVD risk than men; however, with menopause, the risk among women rapidly reaches the levels seen in men, especially after 50 years of age $(15,22)$. The risk of developing CVD increases with BMI in men and women with age (24). The percentage of overweight and obese participants included in the sample was $18.8 \%$ for men and $22.1 \%$ for women. The percentage of men who had an unacceptable waist-to-hip ratio was $16.3 \%$; this rate was $35.8 \%$ for women. These results suggest that the difference in CVD prevalence between men and women might disappear in the near future. It is known about the role of psychological factors in the development of heart disease in women (25). In the premenopausal time, women have extra protection from CVD, as evident by a 10 - to 20-year delay in theonset of CVD among women when compared to men $(26,27)$. Recent data showed that mortality and morbidity of the women with regard to CVD are rising significantly since 1980 (28).

Increases in the students' knowledge of CVD risk factors were associated with decreases in blood glucose and cholesterol values. There are studies showing that as CVD knowledge level increases, disease results improve $(14,29,30)$. The data obtained reflect this expected result. Researchers have studied the role in the development of the atherosclerosis and the increase of CVD risk for decades. Successful intervention programs in a number of countries have supported the casual link between the casual link between dyslipidemia and CVD by demonstrating that reductions in cholesterol lead to descreased CVD morbidity and mortality (31).

\section{CONCLUSION}

The knowledge of CVD risk factors among nursing students was low; female students were at a higher cardiovascular risk than male students and an increase in the knowledge of CVD risk factors had a positive effect on the anthropometric measurement results. To control the CVD risk factors among nursing students, the widespread implementation of this type of screening program and the monitoring of students assessed to be at risk is recommended. These recommendations and the results of this research were submitted to the school management, which highlighted those areas with identified problems.

Limitations of this study;

The study itself involved recruitment from only one site; this could quite markedly limited generalizability of the findings. On the other hand all nursing students at the studied school were expected to participate in the screening program; therefore, no sample calculations were made. However, because this screening contained invasive procedures, only the students who provided consent participated in the study, following the principle of voluntary participation. Therefore, students were not randomly included in the study. Also the CARRF-KL scale is a scale developed to measure the knowledge level of the individuals who did not have a health education 
background. It is thought that the questions may have been easy for the nursing students, and therefore they may have expected distracters in the questions or have answered them incorrectly because the knowledge level of the students was lower than expected. Improvements are expected if similar studies are conducted with scales designed specifically for the students. Also, it would be better if the data obtained from the risk screening were examined while considering the individual and health-related behaviours of the nursing students.

\section{Acknowledgement}

The authors would like to thank Istanbul University Scientific Research Projects (IU BAP) Unit, which contributed to the study (Project No: 6885); management of school, who allocated a special room for data collection; Sistem Cozum Limited company who provided the digital arterial blood pressure measurement device that was used to collect data and the company representatives, Atalay Budak and Yasin Bayrak; Abbott who provided the glucometer and its strips, and its company representative, Haluk Yıldırım; and all the students who volunteered to participate in the study.

\section{REFERENCES}

[1] Arıkan I, Metintaş S, Kalyoncu YZ. The cardiovascular disease risk factors knowledge level (CARRF-KL) scale: A validity and reliability study. Arch Turk Soc Cardiol 2009;37:35-40.

[2] Martell-Claros N, Galgo-Nafria A. Cardiovascular risk profile of young hypertensive patients: The open joven study. Eur J Prev Cardiovasc 2012;19(3):534-540.

[3] Turhan N. Health Prevention strategies and screening programmes in women and men. J Med Sci 2008;28(6):255261.

[4] Yeşildal N, Aslan D. Nutritional advice in the prevention of cardiovascular diseases. Sted 2003;12(7):248-249.

[5] Samur G. Nutrition in the cardiovascular diseases. Ankara: Sinem Printing House; 2006, p.24-36.

[6] Aparcı M, Kardeşoğlu E, Cebeci BC. Approach to cardiovascular disease in primary care medicine. TAF Preve Med Bull 2007; 6(5):380-388.

[7] Kerimoğlu D, Kın S, Şahin F, Leloğlu S, Elçin Öi, Çırak N, Akın A. The periodic health checks (check-up) results of health centers between 2003-2006 in Hacettepe University. Hacettepe Med J 2007;38:159-166.

[8] Allender S, Scarborough P, Peto V, Rayner M, Leal J, LuengoFernandez R, Gray A. European cardio-vascular disease statistics. 3rd ed. Brussels: European Heart Network; 2008. p.124-136.

[9] Badir A, Tekkas K, Topcu S. Knowledge of cardiovascular disease in Turkish undergraduate nursing students. Eur J Cardiovasc Nurs 2015;14(5):441-449.

[10] Bagriacik N, Onat H, Ilhan B, Tarakci T, Oşar Z, Ozyazar M, Hatemi HH, Yildiz G. Obesity profile in Turkey. Int J Diabetes Metab 2014;17:5-8.

[11] Satman I, Yılmaz T, Sengül A, Salman F, Uygur S, Bastar I, Tütüncü Y, Sargın M, Dinççağ N, Karşıdağ K, Kalaça S, Özcan C, King H. Population-based study of diabetes and risk characteristics in
Turkey: Results of the Turkish diabetes epidemiology study (TURDEP). Diabetes Care 2002;25:1551-6.

[12] Arici M, Turgan Ç, Altun B, Sindel S, Erbay B, Erbay B, Derici U, Karatan O, Erdem Y, Hasanoğlu E, Çağlar S. Hypertension incidence in Turkey (HinT): A population-based study. J Hypertens 2010;28:240-244.

[13] Gall SL, Jamrozikb K, Blizzarda L, Dwyerc T, Venna A. Healthy lifestyles and cardiovascular risk profiles in young Australian adults: the childhood determinants of adult health study. Eur J Cardiovasc Prev Rehabil 2009;16: 684-689.

[14] Eshah NF, Bond AE, Froelicher ES. The effects of a cardiovascular disease prevention program on knowledge and adoption of a heart healthy lifestyle in jordanian working adults. Eur J Cardiovasc Nurs 2010;9:244-253.

[15] Açık Y. Baskil ilçe merkezinde 35 ve üstü yaş grubunda koroner kalp hastalığı risk faktörleri taraması. Fırat Üniversitesi. Sağlık Bilimleri Enstitüsü, Doktora Tezi. 1994 (Turkish).

[16] Efil S. Sağlık çalışanlarında obezite sıklığı ve etkileyen faktörlerin değerlendirilmesi. Afyon Kocatepe Üniversitesi. Sağlık Bilimleri Enstitüsü, Yüksek Lisans Tezi. 2006 (Turkish).

[17] Kark M, Rasmussen F. High systolic blood pressure Increases the risk of obtaining a disability pension because of cardiovascular disease: a cohort study of swedish men. Eur J Cardiovasc Prev Rehabil 2009;16:597-602.

[18] Özdoğan E. HbA1c and blood lipid levels in patients with type 2 diabetes associated with obesity. T.C. Ministry of Health, Istanbul Education and Research Hospital and Family Medicine, Expertise Thesis. 2007.

[19] Yalçın KF. Celal Bayar Üniversitesi bünyesinde bulunan 40 yaş ve üzeri erkek personelde kardiyovasküler hastalık risk faktörü taraması. Celal Bayar Üniversitesi Sağıık Bilimleri Enstitüsü, Yüksek Lisans Tezi, 2006 (Turkish).

[20] Onat A, Büyükbeşe MA, Ural E, Keleş I, Ural D, Ince E, Kurban B, Sansoy V. Investigations $\mathrm{HDL}$-cholesterol and fibrinogen levels and associations with some risk factors in the population of the Marmara region. Arch Turk Soc Cardiol. 1997;25:520-525.

[21] Condon C, McCarthy G. Lifestyle changes following acute myocardial infarction: patients perspectives. Eur J Cardiovasc Nurs 2006;5:37-44.

[22] Görgel BE, Çakıroğlu PF. Women in menopause period. Ankara: Ankara University Press; 2007 (Turkish).

[23] Özyurt BC. The risk of cardiovascular disease in the males 45 years and older living in rural area in manisa. Firat Med J 2010;24(2):101-107.

[24] Dudina A, Cooney MT, De Bacquer D, De Backer G, Ducimetie 're P, Jousilahti P, Keil U, Menotti A, Njølstad I, Oganov R, Sans $S$, Thomsen T, Tverdal A, Wedel $H$, Whincup P, Wilhelmsen L, Conroy R, Fitzgerald A, Graham I. Relationships between body mass index, cardiovascular mortality, and risk factors: A report from the score investigators. Eur J Cardiovasc Prev Rehabil. 2011;18(5):731-742.

[25] Hong S, Friedman J, Alt S. Modifiable risk factors for the primary prevention of heart disease in women. J Am Med Wom Assoc 2003;58(4):278-284.

[26] Castelli WP. Epidemiology of coronary heart disease: The Framingham Study. Am J Med 1984;76(2A):4-12.

[27] Kannel WB, Wilson PW. Risk factors that attenuate the female coronary disease advantage. Arch Intern Med 1995;155(1):5761.

[28] Lowel H, Lewis M, Keil U, Hormann A, Bolte HD, Willich S, Gostomzyk J. Temporal trends in myocardial infarct morbidity, 
mortality and 28-day fatalities and medical management. Results of the Augsburg Myocardial Infarct Register 1985 to 1992. KardiZol 1995;84(8):596-605.

[29] Buckley T, McKinley S, Gallagher R, Dracup K, Moser K, Aitken $L$. The effect of education and counseling on knowledge, attitudes and beliefs about responses to acute myocardial infarction symptoms. Eur J Cardiovasc Nurs 2007;6:105-111.
[30] Thanavaro J, Moore S, Anthony M, Narsavage G, Delicath T. Predictors of poor coronary heart disease knowledge level in women without prior coronary heart disease. J Am Acad Nurse Pract 2006;18(12):574-581.

[31] Fuster V, Kelly BB. Institute of medicine (US) committee on preventing the global epidemic of cardiovascular disease: meeting the challenges in developing counties. Washington: National Academies Press; 2010.p.145-155. 